\title{
Decision to pay dividends and ownership structures in Nigeria
}

\author{
Adamu Idris Adamu* \\ Department of Accounting, \\ Federal University Dutsin-Ma, Nigeria \\ TISSA, Universiti Utara Malaysia, Malaysia \\ Rokiah Ishak \\ Nor Laili Hassan \\ TISSA, Universiti Utara Malaysia, Malaysia \\ *Corresponding author: adamuidris48@gmail.com
}

\section{A R T I C L E I N F O}

Article history:

Received 12 March 2019

Revised 5 August 2019

Accepted 13 August 2019

Published 6 January 2020

Keywords:

Decision to pay dividends, ownership structures, emerging market.

JEL Codes: AG32, G350, G390

\section{A B S T R A C T}

Empirical evidence on how ownership structures influence decision to pay dividends remain unclear in the dividend policy literature. This paper is set to investigate the association between ownership structures and decision to pay dividends. The sample firms of this study consist of nonfinancial firms listed on the Nigerian Stock Exchange for the period 2011 to 2015 with 270 firm-year observations and logit regression models used to examine the relationship. The study revealed strong evidence that institutional investors were positively related to the decision to pay dividends. However, managerial shareholding was found to have an inverse effect on firms' probability to pay dividends.

Additional analysis was carried out only on dividend payers and the results were also consistent with the hypothesis. Despite this, the managerial investors were somehow weak when the sample was reduced to dividend payers. 
Cumulatively, the results are robust and show support of the agency theory and hence, imply that institutional investors in Nigeria have preference for dividend payers.

\section{Introduction}

Dividend policy has been a topical issue over the years and remains a subject of vital concern in modern finance (Baker \& Weigand, 2015). Additionally, Almalkawi, Rafferty, and Pillai (2010) noted that dividend policy has become the top agenda item of managers in the modern corporate world and has emerged as a contending topic in the field of accounting and finance. Karpavičius (2014) also noted that a firm's dividend payout is important in the determination of its value, and dividend stability increases the value of the firm. Hence, dividend is crucial to the shareholders as well as to the firm. The relationship between dividend payout and institutional investors has been empirically documented in the literature (for example, Afza \& Mirza, 2011; Huda \& Abdullah, 2014; Manos, 2003; Miko \& Kamardin, 2015; Short, Zhang, \& Keasey, 2002). However, evidence on the association between decision to pay dividend and institutional ownership is lacking in the academic literature particularly from the emerging market where the institutional setting is distinct from the developed markets. More so, as the decision to pay dividend is a prerequisite to the level of dividend and hence, the decision to pay or not to pay dividend should be determined in the light of institutional investors prior to considering the magnitude of the dividend payout (Idris, Ishak, \& Hassan, 2017).

On the decision to pay dividend, companies are allowed by the regulators to pay dividends only out of its current profits or its revenue reserves (SEC Nigeria, 2013). Likewise, firms are not allowed to borrow on the grounds for dividend payment. However, with regards to the institutional owners, the capital market regulators have mandated these investors (institutional investors and other large shareholders) to actively participate in the firms of which they invest (SEC Nigeria, 2011). The participation will allow them to influence positively in the financial policies of the firms. Moreover, in terms of taxation, the institutional investors have no tax incentive better than other shareholders as dividends are paid net of withholding tax of $10 \%$. Therefore, it is unclear as to whether institutional investors may influence dividend decision or not. Consequently, in Nigeria, on average, the institutional investors have the highest percentage of shareholdings which accounts for about $48 \%$ of the total shares listed on the Nigerian Stock Exchange market (Abor \& Fiador, 2013). Accordingly, these investors may have significant influence on the decision to pay dividend because of their primary objective which is return on equity in the form of dividend. Furthermore, the institutional investors may pay much attention to the economic 
benefits attached to their shareholdings in various firms (Gedajlovic, Yoshikawa, \& Hashimoto, 2005).

This paper tends to empirically explore the potential relationship between decision to pay dividend and ownership structure using data set from Nigeria. Thus, the paper contributes to the dividend literature through examining the role played by institutional and managerial owners on determining whether to pay or not to pay a dividend. It also examines whether there is significant difference between dividend and non-dividend paying firms in relation to their institutional and managerial ownership.

The paper is structured as follows. Section 2 offers literature review and develops the research hypotheses. Section 3 provides a detailed discussion on the data and methodology used in the study. The empirical findings of the paper are reported in Section 4 while the conclusion of the paper is in Section 5.

\section{Review of Literature and Research Hypothesis}

Several legal and corporate governance changes have taken place for the purpose of restructuring and empowering board of directors in handling corporate bodies or inspiring institutional shareholders activism (Kapopoulos \& Lazaretou, 2007). Institutional shareholders are believed to be more knowledgeable and capable of handling self-dealing issues in the firm (Afza \& Mirza, 2011). They argued that the presence of the institutional investor may likely reduce the severity of agency conflicts among competing parties. Invariably, institutional investors are found to be influential in various aspects of the corporate entity's activities. These areas may include executive compensation (Mancinelli \& Ozkan, 2006; Victoravich, $\mathrm{Xu}, \&$ Gan, 2013) enhancement of audit quality (Han, Kang, \& Rees, 2013) earnings management (Hsu \& Koh, 2005), improving firm value (Navissi \& Naiker, 2006) and share price volatility (Dennis \& Strickland, 2002; Rubin \& Smith, 2009). Moreover, institutional investors do influence corporate payout policy (Chang, Kang, \& Li, 2016; Miko \& Kamardin, 2015; Short et al., 2002).

\subsection{Institutional Ownership and Decision to Pay Dividends}

The agency theorists have posited that firm managers are more interested in retaining substantial amount of corporate profits. The retained profits will allow them to have substantial amount of corporate resources within their reach or control and therefore, provide the managers an avenue for empire building (Jensen \& Meckling, 1976). However, paying dividends may help to mitigate agency costs that may arise between shareholders and corporate managers. This is because payment of the dividend by the firm is likely to compel the firm to source for funding from the capital market and hence, expose the firm to monitoring by the market (Easterbrook, 1984; Rozeff, 1982). Extant literature has suggested that institutional ownership is likely to reduce agency conflict by influencing managers to distribute free cash flow to the shareholders (Chang 
et al., 2016; Grinstein \& Michaely, 2005; Jory, Ngo, \& Sakaki, 2017; Miko \& Kamardin, 2015; Short et al., 2002; Sindhu, Hashmi, \& Haq, 2016). Chang et al. (2016) examines how institutional owners influence dividend policy from the agency perspectives. The study establishes a significant positive association between institutional owners and dividend payout. They added that the positive association is more salient when there is weak external monitoring. Further, the study argued that institutional owners may use dividend as a monitoring tool to address agency related problems subject to the financial performance of the firm. Along this line, there is equally strong evidence supporting the argument that higher dividends increase the stake of institutional investors (Jory et al., 2017).

However, from the tax clientele view of dividends, Allen, Antonio, and Welch (2000) posited that tax incentives attract more institutional shareholders in the U.S. market to invest in dividend paying firms than non-dividend paying firms. From the emerging markets, the evidence also supports the proposition that institutional investors and dividend payout are positively correlated. Sindhu et al. (2016) observed that strong positive relationship prevails between institutional investors and dividend payouts from the Pakistani market. The study showed that institutional investors used dividends as a mechanism for monitoring managers with a view to mitigate agency problem. The result is consistent with the previous evidence advanced by Miko and Kamardin (2015) from Nigeria that also reveals statistically strong association between dividend payout and institutional ownership. The study suggested that institutional investors force managers to disgorge free cash flow from the firm such that managers may not have excess to embark on empire building or perquisite consumption. Likewise, Francis, Hasan, John, and Song (2011) found that decision to pay dividends by firms tends to increase when the shares held by institutional owners increases. Recently, the result of Jacob, Jijo and Lukose (2018) suggest that institutional ownership has significant positive effects on the propensity to pay dividends. Overall, the demand for dividends by institutional investors is in line with the indirect monitoring of managers and free riding arguments (Short et al., 2002). Based on these theoretical explanations, the study hypothesized that;

$\mathrm{H}_{1}$ : Positive relationship prevails between institutional ownership and decision to pay dividends.

\subsection{Managerial Ownership and Decision to Pay Dividends}

Agency theory has suggested that dividend payouts could be used as a mechanism to reduce agency costs and to control particular set of investors from gaining far above the other set (Rozeff, 1982). Managerial ownership is used interchangeably with insider ownership, directors' holdings among others (Farinha, 2003; Francis et al., 2011; Sanda, Mikailu, \& Garba, 2010; Short et al., 2002). Dividend policy is among the techniques that provide control in a firm against potential agency problems. The probability of managers owning a stake in a company may portray the likelihood of alleviating agency problems (Jensen 
\& Meckling, 1976). The argument is that, because the managers form part of the shareholders, they may not go against the interests of other shareholders by wasting the accumulated cash. This is because such an act may affect the entire shareholders of the firm. The arguments on the relationship between managerial ownership and dividend payout are based on a monitoring effect (Florackis, Kanas, \& Kostakis, 2015; Francis et al., 2011; Short et al., 2002). The monitoring hypothesis suggests that managerial ownership and dividend policy are inversely related, implying that managers are likely to pursue projects that maximize shareholder value. Consistent with this argument, evidence from the Nigerian market supports the agency theory prediction on the association between managerial ownership and dividend payout (Dandago, Farouk, \& Muhibudeen, 2015; Miko \& Kamardin, 2015; Ullah, Fida, \& Khan, 2012). The studies found negative association between managerial ownership and dividend payout. The results are also in agreement with extant literature (Al-Amarneh \& Yaseen, 2014; Rizqia \& Aisjah, 2013; Sindhu et al., 2016). That inverse correlation exists between shares held by managers and dividend policy. $\mathrm{Hu}$ and Kumar (2004) also reported that firms with low insider ownership are more likely to pay dividends to the shareholders and Francis et al. (2011) documented that the likelihood to pay dividends decreases with an increase in managerial shareholding. More recently, Farooq and Ahmed (2019) showed that insider ownership is negatively related to the likelihood of dividend payment; hence, consistent with the agency theory.

$\mathrm{H}_{2}$ : Managerial ownership is negatively associated with decision to pay dividends.

\section{Methodology}

The sample for the data analysis of this paper consists of non-financial firms listed on the Nigerian Stock Exchange for the period 2011 to 2015. The choice of period for instance, marked the implementation of the 2011 Code of corporate governance and the end of the financial crisis; whereas, the choice of 2015 was due to availability of data used for the study. The study excludes financial firms for two reasons. Firstly, financial firms are governed by financial regulatory authorities such as the Central Bank of Nigeria (CBN), Nigeria Deposit Insurance Corporation (NDIC) and Nigerian Insurance Commission (NAICOM). These regulatory authorities for example $\mathrm{CBN}$, requires banks to adequately provide for minimum capital adequacy ratio, cash reserve either low or moderate and a non-performing loan ratio not exceeding $5 \%$ prior to paying dividends to the shareholders. Secondly, prior studies on decision to pay dividends excludes financial firms from the final sample of their investigations (see for example, Baker, Dutta, \& Saadi, 2008; Chang et al., 2016; Francis et al., 2011; Idris et al., 2017; Pucheta-Martínez \& López-Zamora, 2017) and factors affecting dividend policy varies from financial to non-financial firms (Baker et al., 2008). The data 
were collected from the annual report of individual firms. The annual reports were obtained simultaneously from individual websites of the firms and the NSE website. The model of the study is as follows and is used in testing the hypotheses of the study.

$$
\begin{aligned}
& \text { DIVDUM } i=\beta_{0}+\beta_{1} \text { INSTDUM } i+\beta_{2} \text { MANGOWS } i+\beta_{3} \text { FSIZE } i+\beta_{4} \text { RETE } i+ \\
& \beta_{5} \text { FLEV } i+\beta_{6} \text { LNSALE } i+\beta_{\mathrm{j}} \text { YEAR } i+\beta_{\mathrm{k}} \text { INDUSTRY } i+\varepsilon i
\end{aligned}
$$

Besides the two variables of interest, institutional and managerial ownership, the study includes various control variables that were found to be important in the literature on the decision to pay dividends. Firm size, retained earnings, leverage and sales and their definitions and sources are provided in Table 3.1. The study also controls for year effect using five dummies. The use of the year dummy is important as 2011 was the year that marked the implementation of the new SEC code of corporate governance and demanded that the institutional owners to actively participate in its enforcement of the industry effect. Likewise, ten dummies have been used for the industry effect. This is because the decision to pay dividends may be affected by the industry as the number of firms within the industries is not evenly distributed. Prior studies such as (Francis et al., 2011; Jiraporn, Kim, \& Kim, 2011; Liljeblom \& Maury, 2016; Sharma, 2011) have considered year and industry effect while studying propensity to pay dividends.

\begin{tabular}{|c|c|c|c|}
\hline Variable & Description & $\begin{array}{l}\text { Expected } \\
\text { sign }\end{array}$ & Source \\
\hline DIVDUM & $\begin{array}{l}\text { Dummy variable } \\
\text { that takes the value } \\
\text { of } 1 \text { if the firm pays } \\
\text { dividends and } 0 \text { if } \\
\text { otherwise. }\end{array}$ & & $\begin{array}{l}\text { (Chang et al., 2016; } \\
\text { Pucheta-Martínez } \\
\text { \& Bel-Oms, 2016; } \\
\text { Pucheta-Martínez \& } \\
\text { López-Zamora, 2017; } \\
\text { Sharma, 2011) }\end{array}$ \\
\hline DIVYLD & $\begin{array}{l}\text { The dividend yield } \\
\text { is estimated as } \\
\text { dividend per share } \\
\text { divided by the share } \\
\text { price at the end of } \\
\text { a year }\end{array}$ & & $\begin{array}{l}\text { (Chang et al., 2016; Hu } \\
\text { \& Kumar, 2004) }\end{array}$ \\
\hline INSTDUM & $\begin{array}{l}\text { Total institutional } \\
\text { ownership ratio } \\
\text { and takes the } \\
\text { value of } 1 \text { if a firm } \\
\text { has institutional } \\
\text { investors and } 0 \text { if, } \\
\text { otherwise. }\end{array}$ & + & $\begin{array}{l}\text { (Chang et al., 2016; } \\
\text { Francis et al., 2011; } \\
\text { Jory et al., 2017) }\end{array}$ \\
\hline MANGOWS & $\begin{array}{l}\text { Management } \\
\text { ownership is the } \\
\text { total percentage of } \\
\text { equity owned by a } \\
\text { firm's directors. }\end{array}$ & - & $\begin{array}{l}\text { (Francis et al., 2011; } \\
\text { Pucheta-Martínez \& } \\
\text { López-Zamora, 2017; } \\
\text { Sindhu et al., 2016) }\end{array}$ \\
\hline
\end{tabular}

Table 1. Variable Description 


\begin{tabular}{|c|c|c|c|}
\hline Variable & Description & $\begin{array}{l}\text { Expected } \\
\text { sign }\end{array}$ & Source \\
\hline FSIZE & $\begin{array}{l}\text { Logarithm of total } \\
\text { assets. }\end{array}$ & + & $\begin{array}{l}\text { (Pucheta-Martínez \& } \\
\text { López-Zamora, 2017; } \\
\text { Sharma, 2011) }\end{array}$ \\
\hline RETE & $\begin{array}{l}\text { Retained earnings to } \\
\text { total capital. }\end{array}$ & + & $\begin{array}{l}\text { (DeAngelo, DeAngelo, } \\
\& \text { Stulz, 2006; Francis } \\
\text { et al., 2011; Jiraporn et } \\
\text { al., 2011) }\end{array}$ \\
\hline FLEV & $\begin{array}{l}\text { Total debt divided by } \\
\text { total assets. }\end{array}$ & - & $\begin{array}{l}\text { (Chang et al., 2016; } \\
\text { DeAngelo et al., 2006) }\end{array}$ \\
\hline LNSALE & $\begin{array}{l}\text { Logarithm of annual } \\
\text { sales. }\end{array}$ & $-/+$ & $\begin{array}{l}\text { (Jeon, Lee, \& Moffett, } \\
\text { 2011; Liljeblom \& } \\
\text { Maury, 2016) }\end{array}$ \\
\hline
\end{tabular}

\section{Analysis of Results}

Table 2, Panel A depicts the descriptive statistics of the variable used in the study and only the two variables of interest have been discussed in the summary statistics. Also in Table 2, Panel B provides further summary statistics on the two independent variables. Firms that paid dividends for the sample period on average accounted for $60.7 \%$ per. This indicated that more than half of the listed firms on the NSE paid dividends. Regarding the institutional investors, the average value was $48.6 \%$ with a minimum and maximum of 0.00 and $98.2 \%$, respectively. This statistic showed that there were a considerable number of institutional shareholders in some firms with a few firms having none. This was also the case for managerial ownership. Among the sample firms in this study, managerial ownership was found to have an average value of $7 \%$ and a median of $1 \%$. Furthermore, the highest and lowest value for this variable was 0.00 to $70.8 \%$, respectively.

Table 2. Descriptive Statistics

\begin{tabular}{lccccc}
\hline $\begin{array}{l}\text { Panel A } \\
\text { Variable }\end{array}$ & Mean & Median & Min & Max & Std. Dev. \\
\hline DIVDUM & 0.61 & 1.00 & 0.00 & 1.00 & 0.49 \\
INSTOW & 0.49 & 0.54 & 0.00 & 0.98 & 0.27 \\
INSTDUM & 0.90 & 1.00 & 0.00 & 1.00 & 0.29 \\
MANGOWS & 0.07 & 0.00 & 0.00 & 0.71 & 0.15 \\
FSIZE & 7.04 & 6.97 & 5.78 & 8.36 & 0.71 \\
RETE & 0.14 & 0.14 & -0.67 & 0.57 & 0.31 \\
FLEV & 0.24 & 0.11 & 0.00 & 1.62 & 0.38 \\
LNSALES & 6.87 & 7.00 & 4.00 & 9.00 & 0.89 \\
\hline
\end{tabular}




\begin{tabular}{lccccc}
\hline $\begin{array}{l}\text { Panel A } \\
\text { Variable }\end{array}$ & Mean & Median & Min & Max & Std. Dev. \\
\hline SALES & 39900000 & 7347873 & 26130 & 651000000 & 81600000 \\
\hline $\begin{array}{l}\text { Panel B } \\
\text { (n=89) }\end{array}$ & 2011 & 2012 & 2013 & 2014 & 2015 \\
\hline $\begin{array}{l}\text { Institutional } \\
\text { own=1 }\end{array}$ & 78 & 80 & 81 & 81 & 82 \\
Number & 87.64 & 89.89 & 91.01 & 91.01 & 92.13 \\
$\begin{array}{l}\text { Percent } \\
\text { Manage rial } \\
\text { own=1 }\end{array}$ & & & & & \\
Number & 45 & 46 & 45 & 44 & 43 \\
Percent & 50.56 & 51.69 & 50.56 & 49.44 & 48.31 \\
\hline
\end{tabular}

Note: Divdum is decision to pay dividend and takes the value of 1 if the firm pays dividends and 0 , if otherwise; Instdum is total institutional ownership ratio and takes the value of 1 if a firm has institutional investors and 0 , if otherwise; Mangows is managerial ownership which is the total percentage of equity owned by a firm's directors; Fsize is logarithm of total assets ; Rete is Retained earnings to total capital; Flev is Total debt divided by total assets; Lnsales logarithm of annual sales.

The summary statistics reported in Table 2, Pane B, shows the data in relation to ownership variables. For the institutional investors, there has been a consistent increase. For instance, in 2015, institutional investors accounted for $92 \%$ as compared with $88 \%$ in 2011 . This meant that there was a steady increase in the presence of institutional investors during the sample period. While institutional investors had increased, the managerial owners on the other hand, remain relatively fixed. Evidently, the presence of managerial owners dropped during the study period from 51\% in 2011 to $48 \%$ in 2015 . This result could imply that agency problems may be addressed with the payment of dividends as suggested in prior studies.

Table 3. Correlation

\begin{tabular}{|c|c|c|c|c|c|c|c|c|c|}
\hline & 1 & 2 & 3 & 4 & 5 & 6 & 7 & VIF & Tol \\
\hline 1.DIVDUM & 1.00 & & & & & & & & \\
\hline 2.INSTDUM & $0.16^{* * *}$ & 1.00 & & & & & & 1.21 & 0.83 \\
\hline 3.MANGOWS & $-0.27 * * *$ & $-0.36^{* * *}$ & 1.00 & & & & & 1.39 & 0.72 \\
\hline 4.FSIZE & $0.35 * * *$ & -0.05 & $-0.3 * * *$ & 1.00 & & & & 1.24 & 0.80 \\
\hline 5.RETE & $0.49 * * *$ & $0.15^{* *}$ & $-0.21 * * *$ & $0.24 * * *$ & 1.00 & & & 1.11 & 0.91 \\
\hline 6.FLEV & $-0.10^{*}$ & 0.00 & $0.30 * * *$ & $-0.32 * * *$ & $-0.16^{* * *}$ & 1.00 & & 1.19 & 0.84 \\
\hline 7.LNSALES & $0.09^{*}$ & 0.00 & 0.02 & 0.00 & 0.00 & 0.00 & 1.00 & 1.00 & 0.99 \\
\hline
\end{tabular}

The variables have been defined in Table 4.1 above. * **and *** are significant at $10 \%$, $5 \%$ and $1 \%$, respectively. 
The analysis of correlation is reported in Table 3. The correlation analysis between the dependent and independent variables is to enable the study to ascertain the direction and strength of relationship. From the correlation matrix, the results showed a strong positive association between decision to pay dividends and the presence of institutional owners. It was found to be statistically significant at $1 \%$. Thus, this implied that firms with institutional owners may demand the payment of dividends. Conversely, the association of decision to pay dividends and managerial ownership was found to be negative and was also statistically .... The result of the correction meant that decision to pay dividends and the management holding were inversely related. Furthermore, the correlation also suggested that the presence of institutional owners could result in a low stake in managerial shares.

The result pertaining to Variance Inflation Factor (VIF) test that is reported in Table 3 demonstrates that none of the values for VIF is equal or greater than 10 threshold (Gujarati, 2004). Similarly, the Tolerance (Tol) values in the study were also within the acceptable level that is below the value of 1 . Hence, the collinearity test provided additional evidence on the absence of multicollinearity that could endanger the findings of the study.

Table 4. Univariate Comparison

\begin{tabular}{lccccc}
\hline \multicolumn{2}{l}{ Dividend nonpayers $(\mathrm{n}=175)$} & \multicolumn{4}{c}{ Dividend payers $(\mathrm{n}=270)$} \\
Variable & Mean & Std. Dev. & Mean & $\begin{array}{l}\text { Std. } \\
\text { Dev. }\end{array}$ & t-value \\
\hline INSTDUM & 0.85 & 0.36 & 0.94 & 0.24 & $-3.07^{* * *}$ \\
MANGOWS & 0.12 & 0.19 & 0.04 & 0.10 & $5.18^{* * *}$ \\
\hline
\end{tabular}

The variables have been defined in Table 4.1 above. ${ }^{*},{ }^{* *}$ and $* * *$ are significant at $10 \%$, $5 \%$ and $1 \%$, respectively

A comparison between dividend non-payers and payers revealed further interesting results. Both the mean and the standard deviation suggested that the dividend payers were distinct from non-payers. From the results in Table 4, the nonpayers had a mean value of $85 \%$ which was lower than $94 \%$ for the dividend payers which was statistically significant. The summary statistics implied that the institutional owners were prevalent in the dividend paying firms. In addition to the result of the group mean, the group standard deviation of the non-dividend payers was also different from the dividend paying firms. The non-dividend paying firms had a higher standard deviation of $36.2 \%$ when compared with $23.7 \%$ for the dividend paying firms. Pertinent to the managerial shareholding, the mean value for the non-payers was $11.9 \%$ which was much higher than $3.8 \%$ scored by the dividend payers. Tests of mean differences in this case were statistically significant at $1 \%$. The result could suggest that managers may be more inclined to non-dividend payers than paying firms. 
Table 5. Logit Regression with Robust Standard Errors

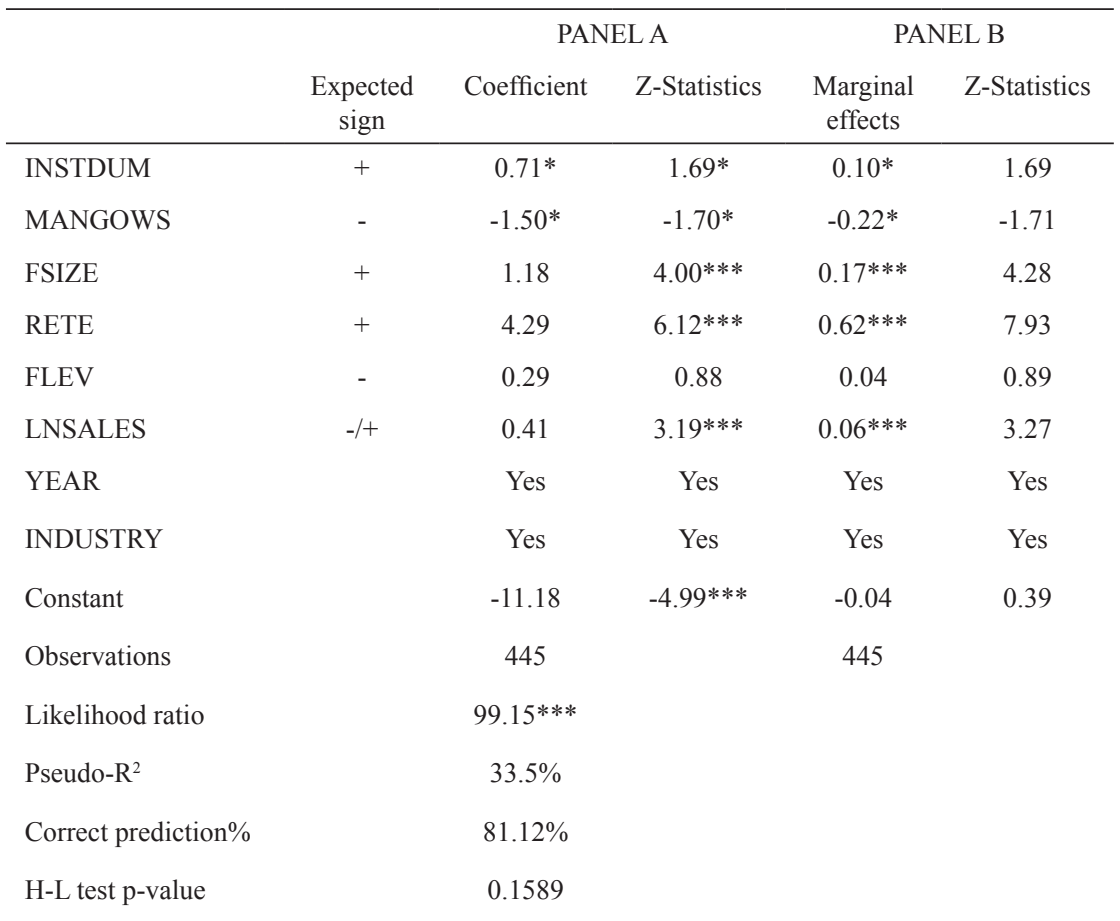

The variables have been defined in Table 4.1 above. * $* *$ and $* * *$ are significant at $10 \%$, $5 \%$ and $1 \%$, respectively.

The study performed regression analysis to get more insights on how ownership affected decision to pay dividends and control for factors that included firm size, retained earnings, leverage and sales in which prior studies had clearly highlighted their importance in dividend policy literature. Table 5 shows the result of the robust logit regression estimation containing estimation based on coefficient and odd ratios along with their z-values. The model had a likelihood ratio Chi-square value of 99.15 and was statistically significant at $1 \%$ with a Nagelkerke pseudo $\mathrm{R}^{2}$ of $33.5 \%$ thus showing the goodness of fit of the model and confirmed the assertion that at least one of the coefficients in the model influenced the decision to pay dividends which was the dependent variable. The study also ran a classification test in order to determine the percentage of correctly predicted cases and how the model predicted group membership. Hosmer, Lemeshow, and Sturdivant (2013) argued that the classification table was an intuitively appealing way that provided a summary of the results of a fitted logistic regression. In this regard, the percentage of group membership correctly predicted by the model was $81.12 \%$ which was far above $50 \%$ the bench mark for a failed model (Pampel, 2000) therefore, suggesting the fitness of the model. Lastly, the Hosmer-Lemeshow test (H-L test) also confirmed the 
model fit of the logit regression as the H-L Chi-square value of 11.83 with an insignificant p-value of 0.1589 .

Table 5 provides the results of the individual variable of interest. The coefficient of the institutional investors was positive and statistically significant at $10 \%$. Furthermore, the results also showed that the presence of institutional investors (INSTDUM) in a firm was more likely to make cash dividend payments which was in line with Hypothesis one $\left(\mathrm{H}_{1}\right)$ and the agency theory. This suggested that institutional investors helped address agency conflict by encouraging dividend payments as a monitoring device. Thus, the result agreed with previous findings (Chang et al., 2016; Francis et al., 2011; Grinstein \& Michaely, 2005; Jacob et al., 2018; Jory et al., 2017; Miko \& Kamardin, 2015; Short et al., 2002; Sindhu et al., 2016) that firms with institutional owners were more likely to pay dividends.

However, managerial ownership (MANGOWS) had a negative and significant effect on the NSE-firms' decision to pay dividends. The logit regression revealed that the coefficient estimates on managerial ownership was negative and statistically significant at $10 \%$. The result suggested that higher managerial shareholding was less likely to lead to more dividend payments. This result corroborated previous studies (Farooq \& Ahmed, 2019; Francis et al., 2011; Hu \& Kumar, 2004; Miko \& Kamardin, 2015; Sindhu et al., 2016) which reported that the likelihood of paying dividends decreased with the increase in managerial shareholding, hence, this was consistent with Hypothesis $2\left(\mathrm{H}_{2}\right)$. The result could suggest that dividend was used in the NSE to curtail the managers from wasting free cash since the managerial holding was on the decreasing path. It has been argued that dividend payments are important as it is part of the optimal monitoring or bonding tool that a firm may use to reduce agency costs (Rozeff, 1982). Alternatively, the result showed that managers in the NSE preferred profit retention instead of disbursing it as dividends to the ordinary shareholders and this could likely lead to perquisite consumption

The result of the control variables employed in the current study revealed firm size and retained earnings to be positive and statistically significant as expected and was consistent with prior evidence (for instance, Jiraporn, Kim, \& Kim, 2011; Liljeblom \& Maury, 2016). Thus, indicating that larger firms with higher retained earnings exhibited a higher likelihood of paying cash dividends. More so, the result of sales revenue was also found to be positive and statistically significant. Hence, suggesting that firms with more sales revenue had a higher probability of paying dividends among the listed firms in Nigeria. This result therefore, supported earlier findings on propensity to pay dividends.

Besides the reported results based on the coefficient of each variable, the study also estimated the marginal effect of the independent variables on outcome. This is to provide further support to the findings of logit regression results with marginal effects, which is depicted in Table 4.3 Panel B. According to Williams (2012), the marginal effect, otherwise referred to as economic significance, was another way by which the effects of variables in nonlinear models such as logit regression analysis could be made more meaningful. In 
other words, the marginal effect provided a representative value for variables in nonlinear models. This paper used the average marginal effect because it was superior than other techniques (Williams, 2012).

The analysis of the marginal effect is reported in Table 5. Both the two variables of interest retained their signs and statistical significance indicating their impact on the decision to pay dividends among the NSE firms. Institutional ownership had a marginal effect of $10.3 \%$ which was positive and statistically significant at $10 \%$. This meant that for every $1 \%$ change on the decision to pay dividends, it followed that, all things being equal, the institutional shareholding increased by $10.3 \%$. The result implied that the presence of institutional investors exerted a greater influence on a firm to pay cash dividends and in turn forced firms to consider raising more funds for investment when necessary in the capital and hence, could result in more market monitoring which in turn agreed with the agency theory (Rozeff, 1982).

Conversely, the marginal effect of the managerial shareholding although it was negative, was higher than the reported marginal effect for the institutional investors as depicted in Table 5, Panel B. The result showed that it was negative and statistically significant which meant that for $1 \%$ additional share of managerial ownership, the decision to pay dividends decreased by $21.8 \%$. This result showed how important managerial shareholding was to firms which could consider paying cash dividends. The negative sign of the association between managerial shareholding and decision to pay dividends further, aligned with the argument advanced by Rozeff (1982) that dividend payout was an optimal mechanism that could be used to reduce agency costs as the stake of the managers declined in the firm.

\subsection{Additional Analysis}

The study also carried out two more additional analysis to ascertain the robustness of the findings (see for example, Al-Najjar \& Kilincarslan, 2016; Chang et al., 2016; Francis et al., 2011; Hu \& Kumar, 2004). In the first specification, the study classified the firms into low and high based on their dividend yield and estimated the model using logit regression with robust standard errors specifications. The result was reported in Table 4.3. Interestingly, the model fitness was also found to be statistically significant at $1 \%$ with a Chi-Square value of 59.85 and pseudo $\mathrm{R}^{2}$ of $35.03 \%$. Moreover, the coefficient of the two key variables retained their signs with institutional shareholding becoming more significant than in the main model of Table 3 . The result showed that institutional shareholding was positive and statistically significant at $1 \%$, indicating that institutional shareholders were concerned about firms that paid higher dividends. The results also confirmed the agency theory argument that institutional investors may use dividend as a form of control mechanism in the firm to avoid free riding problems. For the managerial ownership however, the coefficient was negative though statistically insignificant. But then the negative sign conformed to the agency theory as well which suggested that paying of dividend should be the alternative as the managers' stake decreases in the firm. 
Table 6. Additional Analysis of Dividend Payers

\begin{tabular}{|c|c|c|c|c|c|}
\hline & \multirow[b]{2}{*}{$\begin{array}{l}\text { Expected } \\
\text { sign }\end{array}$} & \multicolumn{2}{|c|}{ PANEL A } & \multicolumn{2}{|c|}{ PANEL B } \\
\hline & & Coefficient & Z-Statistics & Coefficient & t-Statistics \\
\hline INSTDUM & + & 2.04 & $2.93 * * *$ & 0.018 & $1.98^{* *}$ \\
\hline MANGOWS & - & -0.94 & -0.80 & 0.035 & $1.67^{*}$ \\
\hline FSIZE & + & 1.06 & $2.66^{* * *}$ & 0.000 & 0.02 \\
\hline RETE & + & 4.62 & $4.89 * * *$ & 0.012 & 1.45 \\
\hline FLEV & - & 0.78 & $1.68 *$ & 0.003 & 0.60 \\
\hline LNSALES & $-/+$ & 0.34 & $1.91^{*}$ & 0.000 & 0.12 \\
\hline YEAR & & Yes & Yes & Yes & Yes \\
\hline INDUSTRY & & Yes & Yes & Yes & Yes \\
\hline Constant & & -11.85 & $-3.76^{* * *}$ & -0.005 & -0.16 \\
\hline Observations & & 223 & & 270 & \\
\hline Likelihood ratio & & $59.85^{* * *}$ & & & \\
\hline Pseudo- $\mathrm{R}^{2}$ & & $35.03 \%$ & & & \\
\hline Correct prediction $\%$ & & $76.68 \%$ & & & \\
\hline H-L test p-value & & 0.6259 & & & \\
\hline $\mathrm{R}^{2}$ & & & & 10.05 & \\
\hline F-Stat & & & & $2.12 * * *$ & \\
\hline
\end{tabular}

In the second stage of the additional test, the study used a continuous dependent variable known as dividend yield which was consistent with previous studies (for instance, Chang et al., 2016; Hu \& Kumar, 2004) with only dividend payers as the sample firms for the estimation. In this case the F-statistic was 2.12 which was significant at $1 \%$ with the $\mathrm{R}^{2}$ value of $10.05 \%$ thus, suggesting the fitness of the model. The result from this estimation showed that institutional shareholding was highly significant which supported the stated hypothesis of the study and prior evidence. While institutional shareholding remained positively significant, the coefficient of the managerial shares in the firm reversed from negative to positive and was statistically significant thus contradicting the earlier findings of the main results. The results may be interpreted as a form of managerial entrenchment. According to the entrenched view, a manager may use dividends to safeguard his position (Farinha, 2003). Therefore, he or she may be more likely to pay greater dividends so that he/she portrays the identity of a good manager who protects or aligns his/her interests with those of other shareholders. Moreover, it is possible that the dividend payers had more committed and entrenched managers. Jo and Pan (2009) posited that managers may be committed to their responsibilities voluntarily to save their jobs which may in turn limit their opportunistic behaviour. 
Consequently, the results of Table 5 and 6 suggest that the presence of institutional investors in the firm may lead to the likelihood of making cash dividends in the firm; whereas, managerial shareholding may decrease the probability of paying dividends.

\section{Conclusion}

In this paper we analyse how institutional and managerial shareholdings affect the decision to pay cash dividends. A logit regression was used to estimate the effect these variables had on the decision to pay dividends. Consequently, the results of this study suggested the importance of large scale ownership. The study provides that the presence of institutional investors in the firm may lead to a likelihood of making cash dividend payments. The likelihood of paying the dividends becomes more prevalent in firms with higher dividend yields. The results also showed that institutional investors may use dividends as a control tool to avoid free-riding problems in addressing agency conflicts.

Whereas, the relationship between managerial shareholdings and the probability of paying dividends were inversely related which also lend support to the agency theory. The policy implication of this finding is that regulatory bodies may consider all institutional and managerial owners irrespective of whether their holdings is $5 \%$ or below in the enforcement of good governance and policies such as taxation. Moreover, further studies could consider combining these ownership variables with board independence and gender diversity. Such an approach could provide more insights on how large owners may be influenced by board structures. This approach could also enhance the level of our understanding on ownership structures. In addition, it will be useful if future researchers consider various classes of institutional investors separately such as banks, discount houses, pension institutions and insurance firms in analysing their individual roles on firms' decision to pay dividends.

\section{References}

Abor, J., \& Fiador, V. (2013). Does corporate governance explain dividend policy in Sub-Saharan Africa? International Journal of Law and Management, 55(3), 201-225. https://doi.org/10.1108/17542431311327637

Afza, T., \& Mirza, H. H. (2011). Institutional shareholdings and corporate dividend policy in Pakistan. African Journal of Business Management, 5(22), 8941-8951. https://doi.org/10.5897/AJBM11.564

Al-Amarneh, A., \& Yaseen, H. (2014). Corporate governance and dividend policy in Jordan. International Journal of Economics and Finance, 6(4), 200-207. https://doi.org/10.5539/ijef.v6n4p210

Al-Malkawi, H. N., Rafferty, M., \& Pillai, R. (2010). Dividend policy: A review of theories and empirical evidence. International Bulletin of Business Administration, 9(9), 171-200. 
Al-Najjar, B., \& Kilincarslan, E. (2016). The effect of ownership structure on dividend policy: Evidence from Turkey. Corporate Governance: The International Journal of Business in Society, In Press. https://doi. org/10.1108/CG-09-2015-0129

Allen, F., Antonio, E. Eb., \& Welch, I. (2000). A theory of dividends based on tax clienteles. The Journal of Finance, LV(6), 2499-2536. https://doi. org/10.1111/0022-1082.00298

Baker, H. K., Dutta, S., \& Saadi, S. (2008). Impact of financial and multinational operations on manager perceptions of dividends. Global Finance Journal, 19(2), 171-186. https://doi.org/10.1016/j.gfj.2007.11.002

Baker, H. K., \& Weigand, R. (2015). Corporate dividend policy revisited. Managerial Finance, 41(2), 126-144. https://doi.org/http://dx.doi. org/10.1108/MF-03-2014-0077

Chang, K., Kang, E., \& Li, Y. (2016). Effect of institutional ownership on dividends: An agency-theory-based analysis. Journal of Business Research, 69(7), 2551-2559.

Dandago, K. I., Farouk, M. A., \& Muhibudeen, L. (2015). Corporate shareholding structure and dividend payout ratio of listed chemical and paint companies in Nigeria. Applied Finance and Accounting, 1(2), 47-54. https://doi. org/10.11114/afa.v1i2.789

DeAngelo, H., DeAngelo, L., \& Stulz, R. M. (2006). Dividend policy and the earned/contributed capital mix: A test of the life-cycle theory. Journal of Financial Economics, 81(2), 227-254. https://doi.org/10.1016/j. jfineco.2005.07.005

Easterbrook, F. H. (1984). Two agency-cost explanations of dividends. American Economic Review, 74(4), 650-659. https://doi.org/10.2307/1805130

Farinha, J. (2003). Dividend policy, corporate governance and the managerial entrenchment hypothesis: An empirical analysis. Journal of Business Finance and Accounting, 30(9-10), 1173-1209. https://doi.org/10.1111/ j.0306-686X.2003.05624.x

Farooq, O., \& Ahmed, N. (2019). Dividend policy and political uncertainty: Evidence from the US presidential elections. Research in International Business and Finance, In press. https://doi.org/10.1016/j. ribaf.2019.01.003

Florackis, C., Kanas, A., \& Kostakis, A. (2015). Dividend policy, managerial ownership and debt financing: A non-parametric perspective. European Journal of Operational Research, 241(3), 783-795. https://doi. org/10.1016/j.ejor.2014.08.031

Francis, B. B., Hasan, I., John, K., \& Song, L. (2011). Corporate governance and dividend payout policy: A test using antitakeover legislation. Financial Management, 40(1), 83-112. https://doi.org/10.1111/j.1755053X.2010.01135.x

Gedajlovic, E., Yoshikawa, T., \& Hashimoto, M. (2005). Ownership structure, investment behaviour and firm performance in Japanese manufacturing industries. Organization Studies, 26(1), 7-35. https://doi. org/10.1177/0170840605046346 
Grinstein, Y., \& Michaely, R. (2005). Institutional holdings and payout policy. Journal of Finance, 60(3), 1389-1426. https://doi.org/10.1111/j.15406261.2005.00765.x

Gujarati, D. N. (2004). Basic econometrics. McGraw-Hill international (Economic s). New York: McGraw-Hill international. https://doi. org/10.2307/2344828

Hosmer, D. W., Lemeshow, S., \& Sturdivant, R. X. (2013). Applied logistic regression (3rd ed.). Hoboken, New Jersey: John Wiley \& Sons, Inc.

Hsu, G. C. M., \& Koh, P. S. (2005). Does the presence of institutional investors influence accruals management? Evidence from Australia. Corporate Governance, 13(6), 809-823. https://doi.org/10.1111/j.14678683.2005.00472.x

$\mathrm{Hu}$, A., \& Kumar, P. (2004). Managerial entrenchment and payout policy. Journal of Financial and Quantitative Analysis, 39(04), 759. https://doi. org/10.1017/S0022109000003203

Huda, N., \& Abdullah, M. N. (2014). Relationship between ownership structure and dividend policy: Empirical evidence from Chittagong Stock Exchange. World Review of Business Research, 4(3), 14-34.

Idris, A. A., Ishak, R., \& Hassan, N. L. (2017). Is there relationship between board structures and dividend policy: Evidence from Nigeria. Journal of Advanced Research in Business and Management Studies, 9(1), 10-20.

Jacob, C., Jijo, J., \& Lukose, P. (2018). Institutional ownership and dividend payout in emerging markets: Evidence from India. Journal of Emerging Market Finance, (17), 1-29. https://doi.org/10.1177/0972652717751538

Jensen, M. C., \& Meckling, W. H. (1976). Theory of the firm : Managerial behavior, agency costs and ownership structure. Journal of Financial Economics, 3(4), 305-360. https://doi.org/http://dx.doi. org/10.1016/0304-405X(76)90026-X

Jeon, J. Q., Lee, C., \& Moffett, C. M. (2011). Effects of foreign ownership on payout policy: Evidence from the Korean market. Journal of Financial Markets, 14(2), 344-375. https://doi.org/10.1016/j.finmar.2010.08.001

Jiraporn, P., Kim, J. C., \& Kim, Y. S. (2011). Dividend payouts and corporate governance quality: An empirical investigation. Financial Review, 46(2), 251-279. https://doi.org/10.1111/j.1540-6288.2011.00299.x

Jo, H., \& Pan, C. (2009). Why are firms with entrenched managers more likely to pay dividends? Review of Accounting and Finance, 8(1), 87-116.

Jory, S. R., Ngo, T., \& Sakaki, H. (2017). Institutional ownership stability and dividend payout policy. Managerial Finance, 43(10), 1170-1188.

Kapopoulos, P., \& Lazaretou, S. (2007). Corporate ownership structure and firm performance: Evidence from Greek firms. Corporate Governance: An International Review, 15(2), 144-158. https://doi.org/10.1111/j.14678683.2007.00551.x

Karpavičius, S. (2014). Dividends: Relevance, rigidity, and signaling. Journal of Corporate Finance, 25, 289-312. https://doi.org/10.1016/j. jcorpfin.2013.12.014 
Liljeblom, E., \& Maury, B. (2016). Shareholder protection, ownership, and dividends: Russian Evidence. Emerging Markets Finance and Trade, 52(10), 2414-2433. https://doi.org/10.1080/1540496X.2015.1073991

Mancinelli, L., \& Ozkan, A. (2006). Ownership structure and dividend policy: Evidence from Italian firms. The European Journal of Finance, 12(3), 265-282. https://doi.org/10.1080/13518470500249365

Manos, R. (2003). Dividend policy and agency theory: Evidence on Indian firms. South Asia Economic Journal, 4(2), 275-300.

Miko, N. U., \& Kamardin, H. (2015). Ownership structure and dividend policy of conglomerate firms in Nigeria. Academic Journal of Interdisciplinary Studies, 4(2), 279-286.

Pampel, F. C. (2000). Logistic regression: A primer. Sage university series on quantitative applications in social sciences. Thousand Oaks, CA: SAGE Publications.

Pucheta-Martínez, M. C., \& Bel-Oms, I. (2016). The board of directors and dividend policy: The effect of gender diversity. Industrial and Corporate Change, 25(3), 1-25. https://doi.org/10.1093/icc/dtv040

Pucheta-Martínez, M. C., \& López-Zamora, B. (2017). How foreign and institutional directorship affects corporate dividend policy. Investment Analysts Journal, 46(1), 44-60. https://doi.org/10.1080/10293523.2016 .1253136

Rizqia, D. A., \& Aisjah, S. S. (2013). Effect of managerial ownership, financial leverage, profitability, firm size, and investment opportunity on dividend policy and firm value. Research Journal of Finance and Accounting, 4(11), 120-130.

Rozeff, M. S. (1982). Growth, beta and agency costs as determinants of dividend payout ratios. Journal of Financial Research, 5(3), 249. https://doi. org/10.1111/j.1475-6803.1982.tb00299.x

Sanda, A. U., Mikailu, A. S., \& Garba, T. (2010). Corporate governance mechanisms and firms' financial performance in Nigeria. Afro-Asian J. of Finance and Accounting, 2(1), 22-39. https://doi.org/10.1504/ AAJFA.2010.035193

SEC Nigeria. Code of corporate governance (2011).

SEC Nigeria. Securities and exchange commission rules and regulation (2013).

Sharma, V. (2011). Independent directors and the propensity to pay dividends. Journal of Corporate Finance, 17(4), 1001-1015. https://doi. org/10.1016/j.jcorpfin.2011.05.003

Short, H., Zhang, H., \& Keasey, K. (2002). The link between dividend policy and institutional ownership. Journal of Corporate Finance, 8, 105-122.

Sindhu, M. I., Hashmi, S. H., \& Haq, E. U. (2016). Impact of ownership structure on dividend payout in Pakistani non-financial sector. Cogent Business \& Management, 15(1), 1-11. https://doi.org/10.1080/23311975.2016.1272 815

Ullah, H., Fida, A., \& Khan, S. (2012). The impact of ownership structure on dividend policy evidence from emerging markets KSE-100 index 
Pakistan. International Journal of Business and Social Science, 3(9), 298-307.

Victoravich, L. M., Xu, P., \& Gan, H. (2013). Institutional ownership and executive compensation: Evidence from US banks during the financial crisis. Managerial Finance, 39(1), 28-46. https://doi. org/10.1108/03074351311283559

Williams, R. (2012). Using the margins command to estimate and interpret adjusted predictions and marginal effects. The Stata Journal, 12(2), 308331. 